\title{
PRE-SERVICE TEACHERS' CONFIDENCE IN TEACHING STUDENTS WITH VISUAL IMPAIRMENTS IN INCLUSIVE EDUCATION
}

\author{
INGRID ŽOLGAR, MOJCA LIPEC STOPAR \\ Faculty of Education, University of Ljubljana, Slovenia, kontakt: Ingrid.Zolgar@pef.uni-lj.si
}

Received: 14.1.2016.

Original scientific paper Accepted: 11.4.2016.

UDK: 376.1-056.262

\begin{abstract}
The implementation of inclusive education for students with visual impairments still represents a challenge. The results of different studies have shown that regular teachers generally have misconceptions about visual impairments. Similar results can be found for pre-service teachers. In this study, the focus is on the challenges, questions, and dilemmas of pre-service teachers in relation to the inclusion of students with visual impairments. Pre-service teachers $(N=152)$ in undergraduate teacher education study programmes (preschool education and primary teacher education) and graduate (i.e. MA-level) teacher education study programmes (primary teacher education, art education, subject teacher education) participated in the study. The pre-service teachers rated their confidence in their own knowledge and skills in terms of ten specific tasks related to teaching students with visual impairments. The pre-service teachers evaluated their professional knowledge and skills in the observed areas as insufficient to effectively teach students with visual impairments in mainstream schools. The relationship between confidence level and independent variables (personal experience, first thought, study programme) was analysed. The results showed that there were no significant differences regarding personal experience and study programme; however, there was a significant difference regarding their positive, neutral, and negative first thought. A principal component analysis was conducted to detect interrelationships among items on a scale of self-confidence, and it indicated two components: the first one is related to 'designing and delivering instruction' and the second one is related to 'adapting and modifying the learning environment'. Implications for teacher training and the development of a future course are discussed.
\end{abstract}

Keywords: teacher confidence, inclusive education, pre-service teachers, students with visual impairments

\section{INTRODUCTION}

The field of the education of students with special needs has been experienced significant changes in the last decade. Inclusive education is a global trend; its implementation is demanding and complex, as it presumes the involvement of all professionals in kindergarten/school during the educational process in cooperation with students with special needs, their families, peers, and the entire social environment. The core values of inclusion (Friend \& Bursuck, 2002; Loreman, Earle, Sharma, Forlin, 2007; Martinez, 2003) and research findings emphasize the following elements of inclusive education: positive attitudes of all those involved toward inclusion, a high sense of teaching efficacy, the willingness and ability to adapt one's teaching to meet the individual educational needs of students with disabilities.
A significant body of literature links teacher attitudes and teacher preparation to positive inclusive experiences. The results of the research about attitudes toward the inclusion of students with special needs show an unclear picture: from neutral to negative or even contradictory (Avramidis \& Kalyva, 2007; De Boer, 2012; De Boer, Pijl \& Minnaert, 2011; Griffin-Shirley, Koenig, Layton \& Davidson, 2004; Praisner, 2003; etc.).

De Boer (2012) reports that most teachers have uncertain or negative attitudes about inclusive education and that their knowledge about teaching students with special needs is insufficient. The next important conclusion is that teachers do not feel competent and self-confident to teach students with special needs and are negatively or neutrally oriented. Teachers' attitudes also differ regarding the type of special needs (Brown, Packer \& 
Passmore, 2013; Kef, 2002; Koutrouba, Vamvakari \& Steliou, 2006; Lieberman, Houston-Wilson \& Kozub, 2002; Wall, 2002; etc.): because of the low incidence of visual impairments, teachers are less experienced in teaching students with this type of disability. Consequently, we can expect them to have more irrational beliefs, fears, and dilemmas about teaching students with visual impairments than about working with other groups of children with special needs (Brown et al., 2013; Kef, 2002; Koutrouba et al., 2006; Lieberman et al., 2002; Wall, 2002; Žolgar Jerković \& Kermauner, 2006). As researchers (Ajuwon, Lechtenberger, GriffinShirley, Sokolosky, Zhou, \& Mullins, 2012; Forlin, \& Chambers, 2011; Sharma, Forlin, Loreman \& Earle, 2006; Pearson, 2009; Symeonidou \& Phtiaka, 2009; etc.) have concluded, the time during the pre-service training may be the optimum time to address this problem and to modify any negative attitudes toward students with disabilities and their inclusion.

Research findings in the field of inclusion of children with visual impairments (Bishop, 2004; Davis, 2003; Hafnar, 2006; Hatlen, 1996; Novljan et al., 2005; Žolgar Jerković, 2006; etc.) emphasize the need to provide early intervention services for a child and his/her family, as well as the importance of the following factors: instruction in the area of the expanded core curriculum; parental participation in the educational process, preparing the appropriate learning environment and ensuring the appropriate devices and equipment, and providing professionals with appropriate qualifications to implement educational as well as rehabilitation programmes.

Teacher education programmes now have a major responsibility to ensure that new graduates are prepared to include all students in mainstream classrooms regardless of individual differences. One way to determine whether pre-service teachers are ready for this challenge is to examine their perceived knowledge and skills to implement inclusive practices.

Our previous research in this field has shown that teachers have misconceptions about visual impairments and about people with visual impairments, and therefore, they often narrow their teaching focus only on the students' loss of vision.
Understanding teachers' confidence to teach students with special needs and students with visual impairments can contribute to a better understanding of teacher beliefs, help to shape professional development for teachers, influence the teacher education curriculum, and provide a foundation with a better conception of what it means to be a teacher nowadays (Loreman et al., 2007).

Researchers have suggested that accepting responsibility for teaching a diverse group of students and teachers' confidence in their instructional and management skills can lead to the successful implementation of inclusive education (Avramidis, Bayliss \& Burden, 2000; Jordan, Schwartz \& McGhie-Richmond, 2009).

Slovenian legislation, like that of many other countries, supports inclusion, which allows students with disabilities to attend mainstream schools; about two-thirds of all Slovenian school-aged children with visual impairments (meaning those who are blind or have very poor vision) without major additional disabilities attend mainstream schools. The training of pre-service teachers has to a certain extent followed this trend (e.g. professional seminars, workshops, research, guidelines in legislation), and as a result of this trend, all teacher training programs at the Faculty of Education at the University of Ljubljana have a compulsory course on inclusive education - students acquire a general knowledge of teaching children with different types of disabilities, but they have no practical experience in teaching children with disabilities.

As suggested by the results of the above-mentioned studies, it can be expected that pre-service teachers have a number of stereotypical beliefs and a lack of knowledge of the population of children with visual impairments.

According to the above-stated facts, this study focused on a group of future teachers. In this paper we present one part of a broader study, which focused on various issues of inclusive education including questions and dilemmas that arise from the inclusion of students with visual impairments in their classes, how and where additional information can be obtained, and the importance and frequency of collaboration with others (i.e. with parents, special teachers, other children, other teachers, school 
counsellors). This report is focused on the part of the study that explored the levels of confidence of pre-service teachers in relation to teaching students with visual impairments. It is anticipated that the findings of this study will yield useful information to prepare an additional course, and to promote collaboration between professionals from different backgrounds.

This study examines the following research questions: What are the confidence levels of preservice teachers in teaching students with visual impairments in inclusive education? Are there any differences in the levels of confidence that can be linked to first thought, study programme, and personal experience?

\section{METHOD}

\section{Participants}

The study was conducted in January 2014, and it included 152 pre-service teachers at the Faculty of Education at the University of Ljubljana. The students were all enrolled in either undergraduate teacher education study programmes $(56.6 \%)$ or master's level teacher education study programmes (43.4\%) and were studying either preschool, primary, or teacher education (Table 1).

We included $52 \%$ of all enrolled students at the master's level, $53 \%$ of all enrolled students in the third year of preschool education, and 39\% of all enrolled students in the fourth year of primary teacher education at the undergraduate level. Enrolment in the study programmes for art education and subject teacher education is always lower than for preschool education and primary teacher education, hence the difference in numbers concerning the sample structure by study programmes.

The sample of pre-service teachers within each study programme did not differ according to age

Table 1. Sample structure by study programme

\begin{tabular}{|l|c|}
\hline Study programme & N \\
\hline Undergraduate: preschool education, 3rd year & 42 \\
\hline Undergraduate: primary teacher education, 4th year & 44 \\
\hline Master: primary teacher education & 40 \\
\hline Master: art education and subject teacher education & 26 \\
\hline Total & 152 \\
\hline
\end{tabular}

(the biggest age difference is one year within a study programme) or gender (the students enrolled in different programmes are predominately female).

\section{Instrument}

A questionnaire was designed for the purposes the study. It was focused on the exploration of preservice teachers' confidence about their knowledge and skills regarding teaching students with visual impairments.

The questionnaire first included a hypothetical situation. For a better understanding of their professional role, the students were presented with a hypothetical situation, namely that a student with a visual impairment would be joining the group/ class. The scenario was modified according to the study programme.

"Just before the beginning of the school year you get a job in a kindergarten/school. Three days before the beginning of the school year, the headmaster informs you that a new student with blindness without any additional disabilities will be joining your classroom. The child has about 3\% residual vision. He/she is 4 years old / 8 years old, 3rd grade / 12 years old, 7 th grade.

In the first part of the questionnaire, information on the participants' first thought about the hypothetical situation was obtained: the scenario was followed by a question related to their initial reaction to the hypothetical situation (first thought). There were five given responses and the possibility of an open-ended answer. These categories of responses were designed on the basis of responses to an open question in the context of a preliminary study conducted on a sample of 46 pre-service teachers. The given answers were then classified into three categories: negative ("Oops, blind. Panic!"; "Why me?"), neutral ("I have no knowledge about blindness."), and positive ("Excellent, a new challenge!"; "Do not panic, it will work out.").

The scale included 10 items assessing the respondents' confidence in meeting the special needs of children with visual impairments. The scale thus encompassed general issues related to visual impairment, children's learning challenges, ways to identify such challenges, and how to modify 
teaching techniques to optimize the opportunities for learning and socialization in children with visual impairments. The items that were included in the scale are specific to teaching children with visual impairments and were developed keeping in mind a diverse group of learners and a wide range of their needs. The statements on the rating scale were designed based on the theoretical aspects of successful inclusion (core values of inclusion; aspects of the successful inclusion of students with visual impairments) and the special needs of children with visual impairments, on previous research results in this field, on personal experiences in educating teachers and direct work with students, and on normative regulations within the framework of national legislation.

Example of an instruction from the questionnaire:

"The planning of instruction and the direct teaching of a child with blindness require specific knowledge and skills. To help us establish the areas in which you require additional knowledge and skills, please evaluate your competence in the areas listed below. Mark your answer."

The items were phrased in the following way: For ...item... (1 = I do not have enough knowledge and skills; 2, 3, 4 = I have enough knowledge and skills).

Item 1: adaptation of the environment; Item 2: use of assistive technology; Item 3: adaptation of curriculum and activities; Item 4: adaptation of educational materials; Item 5: inclusion of the child in the school environment; Item 6: support for the child's independence; Item 7: evaluation of the child's achievements; Item 8: assessment of the child's needs; Item 9: strategies of teaching; Item 10: planning and preparation of instruction.

This 10 -item scale required participants to report their degree of confidence about whether they could perform each task listed in the item. Participants rated their confidence on a four-point scale from 1, meaning "no confidence", to 4, meaning "high confidence". The items were totalled to generate a composite score for each component. Higher scores indicate higher perceived confidence in teaching students with visual impairments. In the current study, a Cronbach's alpha coefficient was used to measure the internal consistency of the
10 -item scale, which was $0.887(N=150)$.

The respondents also answered a question about their personal experience with persons with visual impairments (no experience, indirect experience, direct experience).

\section{Data collection and analysis}

Participation in the research was voluntary and anonymous. Before completing the questionnaires, the students were presented with the reasons and purpose for this research as well as the process, and they were encouraged to give answers to the questions that were as concrete as possible. The answers were qualitatively and quantitatively analysed and interpreted.

The quantitative data were processed by the program for statistical data processing of SPSS 20.0, with the following statistical procedure: a descriptive analysis of the variables; differences in the evaluation of their own competences according to their personal experience with persons with visual impairments, to their first thoughts, and to their study programme were examined with a one-way analysis of variance; post-hoc comparisons were performed with a Gabriel test; Cronbach coefficient alpha was used to test internal consistency; because this confidence scale was newly developed, a principal component analysis was conducted to detect interrelationships among items and to explain their common underlying components.

\section{RESULTS}

\section{Principal component analysis}

To analyse the interrelationship among items further, a principal component analysis was conducted on a 10 -item scale in order to determine important components in the data. Data were provided by a relatively large sample of pre-service teachers. The case-to-variable ratio in this study was $15: 1$.

Before the analysis was undertaken, the data were examined to determine suitability for PCA. An examination of the correlation matrix revealed many coefficients of 0.30 or above (Table 1 ). The Kaiser-Meyer-Olkin (KMO) measure of sampling 
Table 1. Pearson's Correlation Matrix

\begin{tabular}{|l|c|c|c|c|c|c|c|c|c|c|}
\hline & $\mathbf{I 1}$ & $\mathbf{I 2}$ & $\mathbf{I 3}$ & $\mathbf{I 4}$ & $\mathbf{I 5}$ & $\mathbf{I 6}$ & $\mathbf{I 7}$ & $\mathbf{I 8}$ & $\mathbf{I 9}$ & $\mathbf{I 1 0}$ \\
\hline $\mathbf{I 1}$ & - & $.550^{* *}$ & $.523^{* *}$ & $.506^{* *}$ & $.275^{* *}$ & $.477^{* *}$ & $.272^{* *}$ & $.198^{*}$ & $.353^{* *}$ & $.345^{* *}$ \\
\hline $\mathbf{I 2}$ & & - & $.552^{* *}$ & $.644^{* *}$ & $.184^{*}$ & $.372^{* *}$ & $.228^{*}$ & $.249^{*}$ & $.281^{* *}$ & $.320^{* *}$ \\
\hline $\mathbf{I 3}$ & & & - & $.657^{* *}$ & $.453^{* *}$ & $.531^{* *}$ & $.346^{* *}$ & $.394^{* *}$ & $.469^{* *}$ & $.513^{* *}$ \\
\hline $\mathbf{I 4}$ & & & & - & $.367^{* *}$ & $.440^{* *}$ & $.326^{* *}$ & $.271^{* *}$ & $.331^{* *}$ & $.408^{* *}$ \\
\hline $\mathbf{I 5}$ & & & & & - & $.581^{* *}$ & $.366^{* *}$ & $.334^{* *}$ & $.451^{* *}$ & $.520^{* *}$ \\
\hline $\mathbf{I 6}$ & & & & & & - & $.609^{* *}$ & $.448^{* *}$ & $.557^{* *}$ & $.523^{* *}$ \\
\hline $\mathbf{I 7}$ & & & & & & & - & $.588^{* *}$ & $.591^{* *}$ & $.568^{* *}$ \\
\hline $\mathbf{I 8}$ & & & & & & & & - & $.598^{* *}$ & $.444^{* *}$ \\
\hline $\mathbf{I 9}$ & & & & & & & & & - & $.755^{* *}$ \\
\hline $\mathbf{I 1 0}$ & & & & & & & & & & \\
\hline
\end{tabular}

Note: $* * p<.00 ; * p<.05$

Table 2. Principal component analysis

\begin{tabular}{|c|c|c|c|}
\hline \multirow[t]{2}{*}{ Item_task } & \multicolumn{2}{|c|}{ Component } & \multirow[t]{2}{*}{ Communality } \\
\hline & 1 & 2 & \\
\hline 9_strategies of teaching & .835 & .202 & .738 \\
\hline 7_evaluation of the child's achievements & .804 & .120 & .661 \\
\hline 10_planning and preparation of instruction & .770 & .286 & .674 \\
\hline 8 assessment of the child's needs & .747 & ,096 & .567 \\
\hline 6_supporting the child's independence & .683 & .416 & .640 \\
\hline 5 including the child in the school environment & .616 & .263 & .449 \\
\hline 2_use of assistive technology & .096 & .845 & .723 \\
\hline 4_adaptation of educational materials & .231 & .819 & .725 \\
\hline 1_adaptation of the environment & .194 & .757 & .610 \\
\hline 3_adaptation of curriculum and activities & .407 & .727 & .694 \\
\hline Eigenvalue & 4.995 & 1.486 & \\
\hline Variance Explained (\%) & 36.069 & 28.747 & \\
\hline Reliability Cronbach's $\alpha$ & .875 & .842 & \\
\hline
\end{tabular}

Kaiser-Meyer-Olkin measure of sampling adequacy $=.843$

Bartlett's test of sphericity: $\chi 2(45)=773.169, \mathrm{p}<0.001$

adequacy was 0.842 , exceeding the recommended value of 0.60 , and all KMO values for individual items were greater than 0.819 , which is well above the acceptability limit of 0.5 (Field, 2009). Bartlett's test of sphericity was also highly significant $\left(\chi^{2}(45)=773.169, p<.001\right)$, indicating the suitability of the data for principal component analysis.

According to the assumptions listed above, the principal component analysis extraction method with Varimax (orthogonal) rotation was used. Kaiser's criterion that only factors with eigenvalues greater than one are retained (eigenvalue $\geq 1$ ) was used to define the number of components that would be kept. The principal component analysis with a Varimax rotation yielded a two-component solution, which accounted for $64.82 \%$ of the variance (Table 2). The first factor had an eigenvalue of 4.995 , which accounted for $36.07 \%$ of the variance, while the eigenvalue of the second factor was 1.486 , which accounted for $28.75 \%$ of the variance.

Six items loaded onto Component 1. Items 9, $7,10,8,6$, and 5 have particularly high loadings $(0.835,0.804,0.770,0.747,0.683$, and 0.616$)$ on the first component, with an eigenvalue of 4.995, which accounted for $36.069 \%$ of the total variance. The first component consists of items that relate to teaching strategies for students with visual impairments, to the evaluation of a child's achievements, to the planning and preparation of instruction, to 
the assessment of a child's needs, to supporting the independence of a child, and to including a child in the school environment. All these items represent "Designing and delivering instruction".

Four items loaded onto the second dimension, related to ensuring high-quality instruction._Items 2 , 4,1 , and 3 have particularly high loadings $(0.845$, $0.819,0.757$, and 0.727 ) on the second component, with an eigenvalue of 1.486 and which accounted for $28.747 \%$ of the total variance. High loadings are registered on the following variables, which relate to the use of assistive technology, to the adaptation and modification of educational materials, to the adaptation and modification of the environment, and to the adaptation and modification of curriculum and activities. This component was named "Adapting and modifying the learning environment".

Internal consistency for each of the components was examined using Cronbach's alpha, for the first component 0.875 , and for the second component 0.842 , which are satisfactory (Table 2). Overall, the analysis indicated that these two distinct dimensions are a good basis for designing an additional course in the future.

\section{Confidence evaluation - confidence in knowledge and skills}

Pre-service teachers rated their confidence in their knowledge and skills on specific tasks related to teaching students with visual impairments. These tasks included adaptation of the environment (Item 1), use of assistive technology (Item 2), adaptation of curriculum and activities (Item 3), adaptation and modification of educational materials (Item 4), including the child in the school environment (Item 5), encouraging the child's independence (Item 6), evaluation of the child's achievements (Item 7), assessment of the child's needs (Item 8), strategies of teaching (Item 9), planning and preparation of instruction (Item 10).

The lowest score prevails in six items $(8,3,2$, 6,4 , and 7) and the highest score in two items (10, 5) (Table 3).

\section{Differences between confidence level and experience, first thought, and study programme}

In order to establish whether pre-service teachers' levels of confidence differ according to the components in regard to their personal experience, first thought, and study programmes, a oneway ANOVA (Table 4) was used.

The participants reported their experiences as follows: nearly two thirds (59.9\%) reported that they had not had any experience with persons with visual impairments, $14.5 \%$ reported that they had previously had indirect experience, and $25.7 \%$ had had direct experience. Levene's test on both components indicated that homogeneity of variance was assumed $(F(2,147)=0.128, p=0.880$ and $F(2,149)=0.412, p=0.663$ respectively). The results from Table 4 showed that there are no significant differences regarding confidence level on both components according to the diverse amount of experience $(F=0.118 ; p=0.889$ and $F=0.361$; $p=0.698$ respectively).

The participants were first asked about their first thought on the hypothetical situation of inclu-

Table 3. Confidence evaluation

\begin{tabular}{|c|c|c|c|c|c|}
\hline Item_task & $\mathbf{N}$ & Mean & SD & Min & Max \\
\hline 8 assessment of the child's needs & 152 & 1.97 & 0.952 & 1 & 4 \\
\hline 3_adaptation of curriculum and activities & 151 & 1.99 & 0.931 & 1 & 4 \\
\hline 2_use of assistive technology & 152 & 2.03 & 1.003 & 1 & 4 \\
\hline 6_supporting the child's independence & 152 & 2.11 & 1.056 & 1 & 4 \\
\hline 4_adaptation of educational materials & 152 & 2.13 & 1.034 & 1 & 4 \\
\hline 7_evaluation of the child's achievements & 152 & 2.13 & 1.094 & 1 & 4 \\
\hline 9_strategies of teaching & 152 & 2.24 & 1.072 & 1 & 4 \\
\hline 1_adaptation of the environment & 151 & 2.32 & 0.990 & 1 & 4 \\
\hline 5_including the child in the school environment & 152 & 2.41 & 1.064 & 1 & 4 \\
\hline 10_planning and preparation of instruction & 152 & 2.43 & 1.132 & 1 & 4 \\
\hline
\end{tabular}


Table 4. Differences in scores on both components according to personal experience, first thought, and the study programme

\begin{tabular}{|c|c|c|c|c|c|c|c|c|}
\hline \multirow[t]{2}{*}{ Component } & \multirow[t]{2}{*}{ Personal experience } & \multirow[t]{2}{*}{$\mathbf{N}$} & \multirow[t]{2}{*}{$\mathbf{M}$} & \multirow[t]{2}{*}{ SD } & \multicolumn{2}{|c|}{$\begin{array}{c}\text { F - Levene test of } \\
\text { Homogeneity of Variances }\end{array}$} & \multicolumn{2}{|c|}{ ANOVA } \\
\hline & & & & & $\begin{array}{c}F \\
(d f 1, \text { df2) }\end{array}$ & $\mathbf{p}$ & $\mathbf{F}$ & p \\
\hline \multirow[t]{3}{*}{1} & no experience & 22 & 7.14 & 2.29 & \multirow{3}{*}{$\begin{array}{c}0.128 \\
(2,147)\end{array}$} & \multirow[t]{3}{*}{0.880} & \multirow[t]{3}{*}{0.118} & \multirow[t]{3}{*}{0.889} \\
\hline & indirect experience & 45 & 7.58 & 3.43 & & & & \\
\hline & direct experience & 82 & 9.28 & 3.17 & & & & \\
\hline \multirow[t]{3}{*}{2} & no experience & 22 & 11.86 & 4.19 & \multirow{3}{*}{$\begin{array}{c}0.412 \\
(2,149)\end{array}$} & \multirow[t]{3}{*}{0.663} & \multirow[t]{3}{*}{0.361} & \multirow[t]{3}{*}{0.698} \\
\hline & indirect experience & 46 & 12.80 & 5.18 & & & & \\
\hline & direct experience & 83 & 13.83 & 5.01 & & & & \\
\hline \multicolumn{9}{|l|}{\begin{tabular}{|l|} 
First thought \\
\end{tabular}} \\
\hline \multirow[t]{3}{*}{1} & Negative & 22 & 7.14 & 2.29 & \multirow{3}{*}{$\begin{array}{c}2.527 \\
(2,146)\end{array}$} & \multirow[t]{3}{*}{0.083} & \multirow[t]{3}{*}{6.518} & \multirow[t]{3}{*}{0.002} \\
\hline & Neutral & 45 & 7.58 & 3.43 & & & & \\
\hline & Positive & 82 & 9.28 & 3.17 & & & & \\
\hline \multirow[t]{3}{*}{2} & Negative & 22 & 11.86 & 4.19 & \multirow{3}{*}{$\begin{array}{c}1.043 \\
(2,148)\end{array}$} & \multirow[t]{3}{*}{0.355} & \multirow[t]{3}{*}{1.615} & \multirow[t]{3}{*}{0.202} \\
\hline & Neutral & 46 & 12.80 & 5.18 & & & & \\
\hline & Positive & 83 & 13.83 & 5.01 & & & & \\
\hline \multicolumn{9}{|c|}{\begin{tabular}{|l} 
Study program \\
\end{tabular}} \\
\hline \multirow[t]{4}{*}{1} & Preschool & 42 & 8.26 & 2.94 & \multirow{4}{*}{$\begin{array}{c}0.856 \\
(3,146)\end{array}$} & \multirow[t]{4}{*}{0.466} & \multirow[t]{4}{*}{2.094} & 0.104 \\
\hline & primary teacher, undergraduate & 42 & 7.74 & 3.11 & & & & \\
\hline & primary teacher, master's & 40 & 9.48 & 3.52 & & & & \\
\hline & art education, subject teacher, master's & 26 & 8.38 & 3.31 & & & & \\
\hline 2 & Preschool & 42 & 12.38 & 4.49 & 0.712 & 0.546 & 1.259 & 0.291 \\
\hline & primary teacher, undergraduate & 44 & 13.64 & 5.43 & $(3,148)$ & & & \\
\hline & primary teacher, master's & 40 & 14.30 & 4.97 & & & & \\
\hline & art education, subject teacher, master's & 26 & 12.58 & 5.01 & & & & \\
\hline
\end{tabular}

ding a student with a visual impairment in their class/group. The participants responded with negative $(14.5 \%)$, neutral $(30.5 \%)$, and positive first thoughts (55\%). Levene's test on both components indicated that homogeneity of variance was assumed $(F(2,146)=2.527, p=0.083$ and $F(2,148)$ $=1.043, p=0.355$ respectively). According to their first thought, there is a statistically significant difference between the pre-service teachers' level of confidence $(F=6.518 ; p=0.002)$ on the first component, but not on the second component $(F=1.615 ; p=0.202)$. To determine the differences between groups, a post hoc analysis was used. Furthermore, a Gabriel test showed that there are significant differences between positive and negative first thoughts $(p=0.01)$ and positive and neutral first thoughts $(p=0.011)$, while the difference between negative and neutral $(p=0.928)$ was not statistically significant. Pre-service teachers with positive first thoughts perceived themselves as most confident about their ability to teach stu- dents with visual impairments compared with the other two groups.

On average, pre-service primary teachers in the master's level programme rated their competence higher on both components in comparison with those in other study programmes, but this difference was not statistically significant on both components $(F=2.094 ; p=0.104$ and $F=1.259$; $p=0.291$ respectively).

\section{DISCUSSION}

This paper has examined the confidence of pre-service teachers within one teacher training institution in order to determine whether they are sufficiently prepared to teach students with visual impairments in inclusive environments. The items on the scale were customized for activity domain they are linked to competence across a wide scope of tasks and activities that determine the quality of teaching students with visual impairments. 
The participants had acquired some basic knowledge about special needs in their teacher preparation programme, but they perceived their professional knowledge and skills as insufficient to effectively teach students with visual impairments in regular schools. Teaching inclusively is a challenge for teachers and demands a certain level of expertise: children with visual impairments are a heterogeneous group, and they differ in terms of the onset, cause, type, and severity of their visual impairments, as well as the impact it has on their educational experience. Children with visual impairments learn differently because in most cases they cannot rely on their vision to provide information. The information they obtain through their other senses is often fragmented, inconsistent, and passive. Since vision also plays a part in a child's social interactions, children with visual impairments may have problems interpreting facial clues and body language and in making friends (Pogrund \& Fazzi, 2002).

The lowest score on confidence evaluation prevailed in the following six items: adaptation of curriculum and activities, adaptation and modification of educational materials, encouraging the child's independence, evaluation of the child's achievements, and assessment of the child's needs. The highest score prevailed in two items: adaptation of the environment and including the child in the school environment. The issue with teaching children with visual impairments is how teachers can adapt and modify the environment to make it accessible through other sensory channels, and how to provide a structured, consistent, and meaningful learning experience.

According to the first thought, the study demonstrated a statistically significant difference between negative and positive first thoughts. Negative beliefs are often the result of fear, which arises from lack of knowledge about visual impairments. One of the reasons is definitely the fact that the incidence of persons with visual impairments is relatively low. Similar claims have been made by Stanovich and Jordan (2002), namely that teachers' fears of not knowing how to teach a person with special needs leads to adverseness towards inclusive practice. Understanding the characteristics of an individual student and awareness of appro- priate teaching strategies are important determinants for acceptance (Ajuwon et al., 2012; Bruns \& Mogharreban, 2007; Appl \& Spenciner, 2008) and lack of knowledge about effective instructional strategies may result in negative attitudes (Sze, 2009, Subban \& Sharma 2007). Negative attitudes "lead to low expectations of a person with a disability" (Forlin, Loreman, Sharma \& Earle, 2009, p. 209), which could lead to reduced learning opportunities. Wall (2002) presented ideas which could enhance positive attitudes toward inclusion: increasing the amount of positive contact with children with visual impairments before the teacher is expected to teach such children, and providing novice teachers with informational visits, reading materials, meetings, and workshops prior to the children entering the classroom.

The principal component analysis revealed thematically linked areas, with a view to identify common dimensions from which an additional course could be prepared. The first dimension is related to designing and delivering instruction, and the second is related to the adaptation and modification of the learning environment. The percentage of children with visual impairments is lower than in other types of disabilities. Teaching these children presents a unique set of challenges for teachers and requires specific skills, knowledge, and abilities in order to be sensitive to all the students' needs, which includes planning the most appropriate adaptations and modifications of the curriculum.

The planning and preparation of an educational program (workshops, lectures etc.) for future teachers and personnel as well as peers of children with visual impairments is focused on concrete strategies and work methods, based on hands-on experience. It is important to provide them with the answers on "how to implement the educational program". Ajuwon, Sarraj, Griffin-Shirley, Lechtenberger \& Zhou (2015, p.133) suggest that "pre-service training needs to focus on general issues related to visual impairment, children's learning challenges, ways to identify such challenges, and how to modify teaching techniques to optimize opportunities for learning and socialization of children with visual impairments".

At the same time, we have to be aware that teamwork is the key to success; joining knowledge 
and experiences from different fields is prerequisite for successful teaching practice and for equal possibilities for everybody. To implement inclusive practices successfully, teachers first need to have knowledge, but they also need the support of teachers of the blind and visually impaired. One of the roles of teachers of the blind and visually impaired is to give teachers and preschool teachers support and help, and to empower them to do quality work in a class/group in which a child with visual impairments is included. Their responsibilities also include offering help to teachers, providing information and knowledge about teaching children with visual impairments, interpreting medical records, advising about the adaptation of materials, activities and devices, cooperating with team members on a regular basis, etc. (Corn, Hatlen, Huebner, Ryan \& Siller, 1995; Olmstead, 2005; Wolffe et al., 2002).

\section{Limitations of this study}

The information gathered by the instrument could be influenced by socially desirable responses owing to the generally accepted and desired inclusion. There may be other attributes or factors that could influence pre-service teachers' perceived confidence in regards to teaching children with visual impairments that we did not consider.

\section{CONCLUSION}

Teacher education programs now have a major responsibility to ensure that new graduates are well prepared to include all students in mainstream classrooms regardless of individual differences. For the successful inclusion of students with visual impairments, it is not enough that an individual is placed in the class; it is necessary to provide support and education to all those involved: teachers, peers, and others. The student with a visual impairment and his/her family, teachers, and sighted peers are all faced with many challenges. Many of these problems can be avoided by appropriate preparation for inclusive education.

The inclusion of individuals with visual impairments in mainstream schools started long before normative rules of inclusive education were established in Slovenia. Nowadays, more and more students with visual impairments attend schools in their home town. Consequently, the role of the professionals who work with them has changed. This changed role is reflected in the content of the occupation in connection with the education of professionals: it demands additional competencies, which have to be integrated into the educational programme of pre-service teachers and teachers for students with visual impairments. Pre-service teachers have to be given an opportunity to acquire field-based experience with students with visual impairments within their practical pedagogical training. In this way, they can gain positive experiences in teaching this group of students, which might then cause a more positive attitude toward future students with this disability.

With additional education we can empower teachers to teach students with visual impairments because these acquired knowledge and skills can help them in the classroom, where they will face diverse needs of their students - and some of the strategies and methods used are in fact universal for all students. A teacher who focuses on the learning environment and is able to adapt and modify to the benefit of all students possesses effective teaching skills.

This study has provided information in regards to pre-service teacher preparation coursework. This information should be valuable in the process of designing an additional course for pre-service and in-service teachers. 


\section{REFERENCES}

Ajuwon, P. M., Lechtenberger, D., Griffin-Shirley, N., Sokolosky, S., Zhou, L., \& Mullins, F. E. (2012). General Education Pre-Service Teachers Perceptions of Including Students with Disabilities in Their Classrooms. International Journal of Special Education, 27(3), 100-107.

Ajuwon, P. M., Sarraj, H., Griffin-Shirley, N., Lechtenberger, D., \& Zhou, L. (2015). Including Students Who Are Visually Impaired in the Classroom: Attitudes of Preservice Teachers. Journal of Visual Impairment \& Blindness (Online), 109(2), 131-140.

Avramidis, E., Bayliss, P., \& Burden, R. (2000). Student teachers' attitudes towards the inclusion of children with special educational needs in the ordinary school. Teaching and Teacher Education, 16(3), 277-293.

Avramidis, E., \& Kalyva, E. (2007). The influence of teaching experience and professional development on Greek teachers' attitudes towards inclusion. European Journal of Special Needs Education, 22(4), 367-389.

Appl, D., \& Spenciner, L. (2008). What Do Pre-Service Teachers See as Their Roles in Promoting Positive Social Environments? I See Myself as a Facilitator of Acceptance. Early Childhood Education Journal, 35(5), 445-450.

Bishop, V. E. (2004). Teaching Visually Impaired Children. Charles C Thomas Publisher.

Brown, C., Packer, T., \& Passmore, A. (2013). Adequacy of the Regular Early Education Classroom Environment for Students with Visual Impairment. Journal of Special Education, 2013, 46(4), 223-232.

Bruns, D. A., \& Mogharreban, C. C. (2007). The gap between beliefs and practices: Early childhood practitioners' perceptions about inclusion. Journal of Research in Childhood Education, 21(3), 229-241.

Corn, A. L., Hatlen, P., Huebner, K. M., Ryan, F. \& Siller, M. A. (1995). The national agenda for the education and children and youths with visual impairments, including those with multiple disabilities. NY: American Foundation for the Blind.

Davis, P. (2013). Including children with visual impairment in mainstream schools: A practical guide. Routledge.

De Boer, A., Pijl, S. J., \& Minnaert, A. (2011). Regular primary schoolteachers' attitudes towards inclusive education: A review of the literature. International Journal of Inclusive Education, 15(3), 331-353.

De Boer, A.A. (2012). Inclusion: a question of attitudes? A study on those directly involved in the primary education of students with special educational needs and their social participation. [Internet]. [cited 2015 Feb 14]. Available from: https://www.rug.nl/research/portal/files/14120991/proefschrift.pdf

Field, A. P. (2009). Discovering statistics using SPSS: and sex and drugs and rock 'n' roll (third edition). London: Sage publications.

Forlin, C., \& Chambers, D. (2011). Teacher preparation for inclusive education: Increasing knowledge but raising concerns. Asia-Pacific Journal of Teacher Education, 39(1), 17-32.

Forlin, C., Loreman, T., Sharma, U., \& Earle, C. (2009). Demographic differences in changing pre-service teachers' attitudes, sentiments and concerns about inclusive education. International Journal of Inclusive Education, 13(2), 195-209.

Friend, M., \& Bursuck, W. D. (2002). Including Students with Special Needs: A Practical Guide for Classroom Teachers. Allyn \& Bacon.

Griffin-Shirley, N., Koenig, A. K., Layton, C. A., \& Davidson, R. C. (2004). A survey of teachers of students with visual impairments: Responsibilities, satisfactions, and needs. RE: view, 36(1), 7.

Hafnar, M. (2006). Sistemska ureditev v Sloveniji. In D. Kobal Grum in B. Kobal (Ed.) Zagotavljanje enakih možnosti za vzgojo in izobraževanje slepih in slabovidnih otrok v Sloveniji. Ljubljana: Društvo za enake možnosti slepih.

Hatlen, P. (1996). The Core Curriculum for Blind and Visually Impaired Students, Including Those with Additional Disabilities. RE: view, 28(1), 25-32.

Jordan, A., Schwartz, E., \& McGhie-Richmond, D. (2009). Preparing teachers for inclusive classrooms. Teaching and Teacher Education, 25(4), 535-542. 
Kef, S. (2002). Psychosocial adjustment and the meaning of social support for visually impaired adolescents. Journal of Visual Impairment \& Blindness (JVIB), 96(01).

Koutrouba, K., Vamvakari, M., \& Steliou, M. (2006). Factors correlated with teachers' attitudes towards the inclusion of students with special educational needs in Cyprus. European Journal of Special Needs Education, 21(4), 381-394.

Lieberman, L. J., Houston-Wilson, C., \& Kozub, F. M. (2002). Perceived barriers to including students with visual impairments in general physical education. Adapted Physical Activity Quarterly.

Loreman, T., Earle, C., Sharma, U., \& Forlin, C. (2007). The Development of an Instrument for Measuring PreService Teachers' Sentiments, Attitudes, and Concerns about Inclusive Education. International Journal of Special Education, 22(1), 150-159.

Martinez, R. (2003). Impact of a graduate class on attitudes toward inclusion, perceived teaching efficacy and knowledge about adapting instruction for children with disabilities in inclusive settings. Teacher Development, $8(3), 473-494$.

Novljan, E., Jelenc, D., Kastelic, L., Kogovšek, D., Lipec-Stopar, M., Pulec lah, S., Vrhovski Mohorič, M., Žolgar, I. (2005). Uvajanje pogojev za inkluzivno šolanje otrok s posebnimi vzgojno izobraževalnimi potrebami - analiza stanja in predlogi. Ciljni raziskovalni program "Konkurenčnost Slovenije 2001 - 2006. Ljubljana, Pedagoška fakulteta.

Olmstead, J. E. (2005). Itinerant Teaching. Tricks of the Trade for Teachers of Students with Visual Impairments, second edition. New York: AFB Press.

Pearson, S. (2009). Using activity theory to understand prospective teachers' attitudes to and construction of special educational needs and/or disabilities. Teaching and Teacher Education, 25(4), 559-568.

Pogrund, R. L., \& Fazzi, D. L. (2002). Early focus: Working with young blind and visually impaired children and their families. American Foundation for the Blind.

Praisner, C. L. (2003). Attitudes of elementary school principals toward the inclusion of students with disabilities. Exceptional children, 69(2), 135-145.

Sharma, U., Forlin, C., Loreman, T., \& Earle, C. (2006). Pre-service teachers' attitudes, concerns and sentiments about inclusive education: An international comparison of the novice pre-service teacher. International Journal of Special Education, 21(2), 80-93.

Stanovich, P. J., \& Jordan, A. (2002). Preparing general educators to teach in inclusive classrooms: Some food for thought. The teacher educator, 37(3), 173-185.

Subban, P., \& Sharma, U. (2005). Understanding educator attitudes toward the implementation of inclusive education. Disability Studies Quarterly, 25(2).

Symeonidou, S., \& Phtiaka, H. (2009). Using teachers' prior knowledge, attitudes and beliefs to develop in-service teacher education courses for inclusion. Teaching and Teacher Education, 25(4), 543-550.

Sze, S. (2009). A literature review: Pre-service teachers' attitudes toward students with disabilities. Education, 130(1), 53-56.

Wall, R. (2002). Teachers' exposure to people with visual impairments and the effect on attitudes toward inclusion. RE: view, 34(3), 111.

Wolfee, K. E., Sacks, S. Z., Corn, A. L., Erin, J. N., Huebner, K. M, Lewis, S. (2002). Teachers of Students with visual Impairments: What are they teaching? Journal of Visual Impairment \& Blindness, 96(5), 293-304.

Žolgar Jerković, I. (2006). Inkluzija na področju slepote in slabovidnosti. V D. Kobal Grum in B. Kobal (Ed.), Zagotavljanje enakih možnosti za vzgojo in izobraževanje slepih in slabovidnih otrok v Sloveniji. Ljubljana: Društvo za enake možnosti slepih.

Žolgar Jerković, I, Kermauner, A. (2006). Poznavanje slepih in slabovidnih - pot do ustrezne obravnave. Sodobna pedagogika, 57, 376-393. 


\section{SAMOPOUZDANJE BUDUĆIH NASTAVNIKA GLEDE POUČAVANJA UČENIKA OŠTEĆENA VIDA U INKLUZIVNOM OBRAZOVNOM OKRUŽENJU}

Sažetak: Implementacija inkluzivnog obrazovanja za učenike oštećena vida i dalje predstavlja izazov. Rezultati prethodnih istraživanja pokazali su da redovni nastavnici obično imaju pogrešne predodžbe o učenicima oštećena vida i njihovom poučavanju. Slični rezultati mogu se naći i kod budućih nastavnika. Cilj ovog rada bio je ispitati izazove, pitanja i dileme budućih nastavnika glede uključivanja učenika oštećena vida u redovnu osnovnu školu. Ispitivanjem su obuhvaćeni budući nastavnici (N = 152) preddiplomskih (predškolski odgoj, razredna nastava) i diplomskih studijskih programa (razredna nastava, predmetna nastava). U istraživanju je korištena Skala za ocjenjivanje pouzdanja u vlastito znanje i vještine poučavanja učenika oštećena vida u redovnoj osnovnoj školi. U promatranim područjima budući nastavnici ocjenjuju svoje profesionalno znanje i vještine za poučavanje učenika oštećena vida u redovnim školama nedovoljnima. Rezultati analize razlika u samopouzdanju budućih nastavnika s obzirom na nezavisne varijable nisu pokazali značajne razlike u pogledu osobnog iskustva i programa studija. Međutim, značajna razlika pokazala se glede njihove pozitivne, neutralne i negativne prve misli. Metodom glavnih komponenata čestica na skali ekstrahirane su dvije dimenzije: prva se odnosi na 'planiranje nastave i poučavanje', a druga se odnosi na 'prilagodbu i modificiranje okoline učenja'.

Ključne riječi: samopouzdanje nastavnika, inkluzivno obrazovanje, budući nastavnici, učenici oštećena vida 